\title{
What young people think and do when the option for cystic fibrosis carrier testing is available
}

\author{
John Mitchell, Charles R Scriver, Carol L Clow, Feige Kaplan
}

\begin{abstract}
We report findings in phase II of a pilot study of cystic fibrosis (CF) carrier screening/testing by mutation analysis. Phase I has been reported elsewhere. Eligible participants in phase II $(n=815)$ were students (15 to 17 years of age) in public high schools. An educational component (exchange of information and discussion about common genetic disorders including CF) preceded, by one week or more, voluntary participation in the screening component which required a blood sample.
\end{abstract}

The uptake rate for screening was $42 \%$. Nine carriers $(2 \mathrm{pq}=0.0260)$ were identified, all with the $\Delta F 508$ mutation; students were also tested for G551D, G542X, W1282X, and -549- mutations, but no carriers of these alleles were found. Carriers had positive views of the education and testing experiences. Persons identified as 'non-carriers' were also surveyed $(n=135$, response rate $41 \%)$. As in phase $I$, the majority (83\%) again understood that a negative DNA test had not excluded them from possible carrier status. Students who participated in the informational component but were not screened served here as controls in the follow up survey $(n=208$, response rate $53 \%)$. Their views were similar to those of the screened non-carriers, and similar also to those held by students, adults, pregnant women, couples, and CF relatives in other communities.

(f Med Genet 1993;30:538-42)

Department of Department of
Pediatrics and Research Institute, Montreal Children's Hospital, Centre for Human Genetics, McGill University, Montreal, Canada. J Mitchell

C R Scriver

C L Clow

F Kaplan

Correspondence to Mr Mitchell, Room A-709, McGill University-Montreal Children's Hospital Research Institute, 2300 Tupper Street, Montreal, Quebec H3H IP3, Canada.

Received 9 November 1992. Revised version accepted 24 December 1992. of the severe autosomal recessive diseases affecting Caucasians. ${ }^{1}$ The carrier frequency is about 1 in 25 among Europeans. Identification and characterisation of the cystic fibrosis transmembrane regulator (CFTR) gene, ${ }^{23}$ and of the most prevalent mutation associated with $\mathrm{CF},{ }^{4}$ has made carrier screening both a possibility and a subject of controversy.

There are reasons for and against CF carrier screening or testing at the present time..$^{5-7} \mathrm{We}$ distinguish here between genetic screening and testing. ${ }^{7}$ The former refers to a test applied to a population, group, or individual person to distinguish between persons carrying a CF mutation and those who do not. Testing implies the use of specific methods to identify the genetic status of consultands known to be at high risk because of a family history. Among the reasons for proceeding with caution is the imperfect sensitivity of a test based on DNA analysis that does not identify all possible CF mutations. For the purposes of reproductive counselling of couples with one known carrier, one can only provide an accurate screening test when the risk falls below the population risk for the disorder. In the case of CF, where carrier frequency $(q)=1 / 25$, this can only be achieved when the proportion of carriers that can be detected exceeds $96 \%{ }^{89}$ So far, this condition has been met in only two populations. ${ }^{1011}$

In the meantime, in keeping with recommendations that pilot studies should be done for genetic screening/testing procedures in general, ${ }^{12}$ and for CF carrier screening in particular, ${ }^{71314}$ we have been conducting a pilot study in Montreal. We report here results from phase II of the project. Our objectives are the same as those that informed phase $I,{ }^{15}$ namely (1) to obtain information on unconditional allele frequencies in the population; (2) to evaluate how well participants understand the limitations in sensitivity of mutation detection for purposes of genetic screening/ testing; and (3) to ascertain their views on genetic screening/testing in general and for carriers of cystic fibrosis alleles in particular.

\section{Methods}

Phase II of the project was conducted in four public high schools during 1991. The schools are the same as those in which pre-pregnancy screening for carriers of Tay-Sachs and $\beta$ thalassaemia alleles has been in progress for the past two decades. ${ }^{1617}$

\section{SUBJECTS}

Persons of Italian descent were heavily represented in phase II ( $54 \%$ of participants). Students aged 15 or over attending high school were eligible for the project. Those who partitake the screening test, served as controls. Participation at all stages was voluntary, with cipated in an information seminar, but did not 
consent of parents, the school board, and the teachers.

\section{UPTAKE}

Students first attended an information session which covered basic genetic principles and relevant information about CF. Pamphlets describing CF, the project, and issues associated with carrier screening were given to each student. Participants in the screening component identified their ancestral origins (ethnic and geographical).

\section{SAMPLE}

Heparinised venous blood was drawn from the antecubital vein and, on the same day, DNA was phenol extracted from leucocytes. Screening took place at least one week after the information session; it was organised within curriculum time on school premises.

\section{TEST RESULTS}

A personal letter explaining the result of mutation analysis was sent to each participant. One or two weeks after the results were sent, carriers were called, counselled further if the letter explaining the significance of carrier status needed clarification, and asked questions relevant to the project (see below). Counselling, with mutation analysis if desired, was offered to family members.

\section{ANALYTICAL METHODS}

DNA was amplified by the polymerase chain reaction (PCR), and analysed for the mutations $\Delta$ F508, G551D, G542X, W1282X, and $-549-$.

\section{EVALUATION}

This component was carried out after the results of the test had been returned to the participants. We distributed a questionnaire to all participants, both carriers and non-carriers. A separate questionnaire was also distributed to persons who had not participated in the screening phase (controls) to evaluate their attitudes and reasons for non-participation. Controls were selected to match the participants according to school attended, gender, and age.

Table 1 Comparison of attitudes of non-carriers in phase I and phase II (\% yes).

\begin{tabular}{|c|c|c|}
\hline & $\begin{array}{l}\text { Phase I } \\
(n=78)\end{array}$ & $\begin{array}{l}\text { Phase II } \\
(n=135)\end{array}$ \\
\hline \multicolumn{3}{|l|}{ Does a negative test for $\Delta F 508$ mean that you can still be } \\
\hline If you were a carrier would it lower your self image? & 21 & 24 \\
\hline Did you learn something useful about CF? & 85 & 78 \\
\hline Did you learn something new about genetic disease in humans? & 84 & 79 \\
\hline Are you satisfied that you were tested? & 84 & 94 \\
\hline $\begin{array}{l}\text { Do you approve of carrier screening in high schools as a form of } \\
\text { pre-pregnancy screening? }\end{array}$ & 96 & 90 \\
\hline $\begin{array}{l}\text { Would you recommend that your friends take the test as it was } \\
\text { offered to you? }\end{array}$ & 93 & 80 \\
\hline Would you want your future partner tested for cystic fibrosis & 93 & 89 \\
\hline carrier status? & 65 & 89 \\
\hline If your partner were a carrier, would it affect your relationship? & 12 & 17 \\
\hline
\end{tabular}

\section{Results}

PARTICIPATION RATES

There were 815 eligible students in phase II of the project; of these, 341 (42\%) participated in both the education and the screening component. Participation rates in the follow up components were $41 \%$ for non-carriers and $78 \%$ for carriers. The response rate was $53 \%$ $(n=208)$ in the control group (students who attended the education component but were not screened).

\section{MUTATION ANALYSIS}

Nine carriers were identified, all with the $\Delta$ F508 mutation. There were no carriers of the G551D, G542X, W 1282X, and -549- alleles. The observed carrier frequency was 0.0260 in phase II. There were 386 chromosomes of Italian descent, four of which carried the $\Delta F 508$ alleles. Accordingly, the unconditional frequency of $\Delta F 508$ carriers in this sample of Italians in Montreal is 0.0208 .

\section{PERCEPTIONS OF CARRIERS}

All carriers believed that their CF carrier status had not harmed their own health. Three had experienced what they considered to be modest anxiety and one had great anxiety on receiving the test result. Anxiety had dissipated in all respondents by the time of the follow up interview. The newly identified carrier status did not affect self-image. Seven carriers expressed interest in having family members tested. They also indicated they would seek further counselling before pregnancy or planning a family. These findings show that carriers in phases I and II of the study held similar views.

\section{PERCEPTIONS OF NON-CARRIERS IN PHASES I} AND II

We compared attitudes among the non-carrier participants in phases I and II (table 1). The great majority $(>83 \%)$ of students in both phases understood that testing only for $\Delta \mathrm{F} 508$ did not rule out carrier status. The majority $(>90 \%$ ) approved of genetic screening in high schools, were satisfied $(>84 \%)$ that they had been tested, would recommend the test to their friends $(>89 \%)$, would want their future partner to be tested ( $>65 \%$ ), and did not think that this would affect their self-image $(>76 \%)$ or future relationships $(>83 \%)$. The majority $(>78 \%$ ) learned something new about genetic disease in general and something useful about CF in particular.

PERCEPTIONS OF CONTROLS (NON-SCREENED STUDENTS)

Knowledge and attitudes among the nonscreened controls $(n=208)$ were compared with screened non-carriers $(n=135)$ (table 2). Attitudes in the two groups were very similar. Among the screened non-carrier respondents, only one expressed disapproval of pre-pregnancy carrier testing, and among the controls 
Table 2 Comparison of knowledge in screened non-carriers and non-screened controls.

\begin{tabular}{lcc}
\hline & $\begin{array}{c}\text { Screened non-carriers }(\mathrm{n}=135) \\
\text { Yes }(\%)\end{array}$ & $\begin{array}{c}\text { Non-screened controls }(\mathrm{n}=208) \\
\text { Yes }(\%)\end{array}$ \\
\hline $\begin{array}{l}\text { Did you learn something useful about CF? } \\
\quad \text { Does CF affect the lungs? }\end{array}$ & 79 & 74 \\
$\quad \begin{array}{l}\text { Does CF affect the pancreas? } \\
\text { Does CF affect the digestive tract? }\end{array}$ & 24 & 29 \\
$\quad$ Does CF affect the brain? & 35 & 34 \\
$\begin{array}{l}\text { Did you learn something about genetic disease in } \\
\text { humans? }\end{array}$ & 79 & 35 \\
$\begin{array}{l}\text { At the present time, does CF shorten life span? } \\
\begin{array}{l}\text { Is CF carrier frequency higher in Caucasians } \\
\text { when compared to other ethnic groups? }\end{array}\end{array}$ & 60 & 76 \\
$\begin{array}{l}\text { Do you approve of genetic screening in high } \\
\text { schools? }\end{array}$ & 63 & 63 \\
\hline
\end{tabular}

Table 3 Comparison of studies surveying attitudes towards CF carrier screening ( $\%$ yes).

\begin{tabular}{|c|c|c|c|c|c|}
\hline $\begin{array}{l}\text { Source, population, } \\
\text { and respondents } \\
\text { to survey }(\mathrm{n})\end{array}$ & $\begin{array}{l}\text { Are you interested } \\
\text { in carrier } \\
\text { screening? }\end{array}$ & $\begin{array}{l}\text { Do you understand } \\
\text { limitations of } \\
\text { DNA test? }\end{array}$ & $\begin{array}{l}\text { Will carrier status } \\
\text { influence your choice } \\
\text { of partner? }\end{array}$ & $\begin{array}{l}\text { Is PND relevant } \\
\text { if both partners } \\
\text { are carriers? }\end{array}$ & $\begin{array}{l}\text { Do you accept } \\
\text { preconceptual } \\
\text { screening? }\end{array}$ \\
\hline $\begin{array}{l}\text { This study } \\
\text { High school students, Montreal } \\
\text { Carriers }(n=7) \\
\text { Non-carriers }(n=135) \\
\text { Controls }\left(n=208^{*}\right)\end{array}$ & $\begin{array}{r}100 \\
90 \\
83\end{array}$ & $\overline{83}$ & $\begin{array}{l}28 \\
17 \\
-\end{array}$ & $\frac{86}{-}$ & $\begin{array}{l}\overline{87} \\
77\end{array}$ \\
\hline $\begin{array}{l}\text { Cobb et al }{ }^{18} \\
\text { Age 14-16, Scotland } \\
(\mathrm{n}=216)\end{array}$ & 86 & - & - & 88 & - \\
\hline $\begin{array}{l}\text { Botkin and Alemagno }{ }^{19} \\
\text { Pregnant women, USA } \\
(n=214)\end{array}$ & - & - & 9 & 67 & 98 \\
\hline $\begin{array}{l}\text { Green }{ }^{20} \\
\text { Couples with children, England } \\
(n=175)\end{array}$ & 83 & - & 11 & 85 & $47 \dagger$ \\
\hline $\begin{array}{l}\text { Decruyenaere } e t a l^{1} \\
\text { Adults, Belgium } \\
(\mathrm{n}=385)\end{array}$ & 76 & - & - & 75 & 86 \\
\hline $\begin{array}{l}\text { Denayer et a } l^{22} \\
\text { Adult } \mathrm{CF} \text { relatives, Belgium } \\
(\mathrm{n}=109)\end{array}$ & 74 & - & 6 & 73 & - \\
\hline $\begin{array}{l}\text { Watson et al } l^{33} \\
\text { Adults, UK } \\
\text { Carriers }(n=88) \\
\text { Non-carriers }(n=111)\end{array}$ & $\overline{-}$ & $\begin{array}{l}46 \ddagger \\
57 \ddagger\end{array}$ & $\overline{16}$ & $\frac{78 \S}{-}$ & $\overline{-}$ \\
\hline
\end{tabular}

* Non-screened subjects were matched to screened carriers and non-carriers.

† Indicates the sum of two choices in a multiple choice question. The most popular single choice was school leavers at $34 \%$.

$\ddagger$ Respondents for this question: carriers $n=26$, non-carriers $n=133$.

$\S$ Answer given after counselling.

only two students held this opinion. The two groups did not differ in their knowledge of CF gained at the education session; in both, the majority $(>74 \%$ ) felt they had learned something useful about the significance of genetic disease in humans. The majority $(>60 \%)$ understood that CF was associated with a shortened life span at present and had the highest prevalence among Caucasians. Reasons for non-participation among the controls included (1) lack of interest $(27 \%),(2)$ fear of a blood test ( $27 \%)$, and (3) failure to complete or return the consent form $(29 \%)$.

PERCEPTIONS IDENTIFIED IN OTHER SURVEYS

We compared findings in our study with those reported in other recent surveys (table 3 ). The actual wording of questions, which were common in content in the various studies, required modification for the sake of clarity in table 3. Our actual questions are listed in the appendix. Views about carrier screening and testing are strikingly similar among several contemporary populations.

\section{Discussion}

Since the discovery of the CF gene in 1989, and identification of the prevalent $\Delta F 508 \mathrm{mu}-$ tation, there has been discussion among geneticists about the potential merits of genetic testing or screening for CF carriers. . $^{51314}$ Meanwhile, we and others (table 3) have gone instead to the community to ascertain the opinions of potential participants. In our pilot study, phase I of which has been previously reported, ${ }^{15}$ we are also obtaining data on unconditional allele frequencies in Quebec populations.

Understanding and attitudes of participants in the second phase of our study did not differ significantly from those observed in the first phase of our project ${ }^{15}$ (table 1). Phases I and II embraced private and public schools respectively with implications about social advantage and other factors that might influence attitudes and understanding. High school students in Scotland ${ }^{18}$ and in Montreal (this study) are indeed interested in the possibility of CF carrier screening for purposes of reproductive counselling. When high school students are 
given the chance to learn and participate, the majority understand and accept the imperfect sensitivity of the DNA test, only a small minority state that carrier status might influence choice of partner, and the majority express familiar views ${ }^{1624}$ about future reproductive decisions. In other studies of opportunistic testing in an antenatal clinic, ${ }^{25}$ general practice, ${ }^{232627}$ and a family planning clinic $^{2326}$ virtually all participants regarded the process as a positive learning experience and accepted the newly gained information. The hypotheti$\mathrm{Cal}^{18-22}$ and opportunistic ${ }^{2325-27}$ studies all indicated similar positive attitudes toward carrier screening in various populations.

Less clear is to what extent the information that can be gained by CF carrier testing with current methods will help family members to deal with the possibility of having an affected offspring. The issue here involves sensitivity of the test, a problem not new to CF carrier testing, and one that we, among others, have examined in other genetic screening programmes in Montreal. ${ }^{28} 29$ Follow up studies, similar to those performed in Tay-Sachs and $\beta$ thalassaemia carrier screening programmes, ${ }^{1630}$ will be necessary to show the effectiveness and impact of information gained from current modes of $\mathrm{CF}$ carrier testing.

Attitudes of participants towards CF carrier screening are very similar in several different populations; they are not apparently influenced by age, social class, level of education (high school and beyond), or country of origin (table 3 ). In communities where opinions were sought, the majority of persons surveyed indicated the 'ideal time' for testing was preconceptual. ${ }^{19-21}$ Such testing can take place in an opportunistic setting, such as a family medical practice or in groups with common ground, such as the high school classroom. Testing in high schools, in our experience, ${ }^{1617}$ has the advantage of efficiency and it can be coupled with a formal educational component. We are aware that the positive findings in Montreal ${ }^{161724}$ may not be representative of other communities.

Participation rates in the screening components of phases I and II in the project were low $(<43 \%)$ compared to about $70 \%$ in the corresponding Tay-Sachs and $\beta$ thalassaemia screening programmes in Montreal. The reasons given for non-participation here were objection to a blood test and possible AIDS infection, failure to bring the signed permission form (a requisite for the pilot study), and lack of interest. Nevertheless these factors clearly did not imply disapproval of screening (table 2 ). When the blood test was replaced by a buccal rinse in phase III, the participation rose to $70 \% .^{31}$

The frequency of detectable CF mutation has reached an 'acceptable' level in two populations ${ }^{1011}$ and is near the desired level in three others. ${ }^{32-34}$ Enhanced public education about CF, development of a more efficient DNA or phenotype test, ability to offer informed counselling to client populations, and maintenance of personal choice when options exist will propel communities to consider what is to be done. The findings described here suggest that young citizens have calm views about CF carrier screening.

We thank Annie Capua, Keo Phommarinh, and Sina Yak for expert technical assistance. The project would not have been possible without the enthusiasm and assistance of the Protestant School Board of Greater Montreal, the Principals, teachers, students, and families associated with the schools. This work was funded in part by The Canadian Genetic Disease Network (Network of Centres of Excellence and MDS Canada), the Medical Research Council of Canada (MRC Genetics Group), and the Quebec Network of Genetic Medicine.

1 Boat TJ, Welsh MJ, Beaudet AL. Cystic fibrosis. In Scriver CR, Beaudet AL, Sly WS, Valle D, eds. The metabolic basis of inherited disease. 6th ed. New York: McGraw Hill Book Co, 1989:2649-80.

2 Kerem BS, Rommens JM, Buchanan JA, et al. Identification of the cystic fibrosis gene: genetic analysis. Science 1989;245:1073-80.

3 Riordan JR, Rommens JM, Kerem BS, et al. Identification of the cystic fibrosis gene: cloning and characterization of complementary DNA. Science 1989;245:1066-73.

4 Rommens JM, Iannuzzi MC, Kerem BS, et al. Identification of the cystic fibrosis genes: chromosome walking and jumping. Science 1989;245:1059-66.

5 Beaudet AL. Invited editorial. Carrier screening for cystic fibrosis. Am $\mathcal{F}$ Hum Genet 1990;47:603-5.

6 Scriver CR, Fujiwara MT. Invited editorial. Cystic fibrosis genotypes and views on screening are both heterogenecus and population related. Am $\mathcal{F}$ Hum Genet 1992;51:943-50

7 Office of Technology Assessment US Congress. Cystic fibrosis and DNA tests: implications of carrier testing. OTA-BA-532. Washington, DC: US Government Printing Office, 1992:vi, 301.

8 Ten Kate LP. Carrier screening in CF. Nature 1989;342:131.

9 Ten Kate LP. Carrier screening for cystic fibrosis and other autosomal recessive diseases. Am $\mathcal{f}$ Hum Gener 1990;47:359-61.

10 Abeliovich D, Lavon IP, Lerer I, et al. Screening for five mutations detects $97 \%$ of CF chromosomes and predicts a mutations detects $97 \%$ of CF chromosomes and predicts a carrier frequency of 1:29 in the Jewish
tion. Am f Hum Genet 1992;51:951-6.

11 Férec C, Audrezet MP, Mercier B, et al. Detection of over $\mathbf{9 8 \%}$ cystic fibrosis mutations in a Celtic population. Nature Genet 1992;1:188-91.

12 National Academy of Sciences Genetic Screening Programs, Principle and Research, Washington DC, 1975.

13 Caskey CT, Kaback MM, Beaudet AL. The American Society of Human Genetics statement on cystic fibrosis screening. Am F Hum Genet 1990;46:393.

14 Workshop on Population Screening for the Cystic Fibrosis Gene. Statement from The National Institutes of Health workshop on population screening for the cystic fibrosis workshop on population screening

15 Kaplan F, Clow C, Scriver CR. Cystic fibrosis carrie screening by DNA analysis: a pilot study of attitudes screening by DNA analysis: a pilot study of attitudes

16 Scriver CR, Bardanis M, Cartier L, Clow CL, Lancaster GA, Ostrowsky JT. $\beta$-thalassemia disease prevention genetic medicine applied. Am f Hum Genet 1984;36:1024 38.

17 Beck E, Blaichman S, Scriver CR, Clow C. Advocacy and compliance in genetic screening: behaviour of physician and clients in a voluntary program of testing for the TaySachs gene. N Engl F Med 1974;291:1166-70.

18 Cobb E, Holloway S, Etlon R, Raeburn JA. What do young people think about screening for cystic fibrosis? If Med Genet 1991;28:322-4.

19 Botkin JR, Alemagno S. Carrier screening for cystic fibrosis: a pilot study of the attitudes of pregnant women. $A m \mathcal{F}$ Sis: a pilot study of the attitude
Pub Health $1992 ; 82: 723-5$.

20 Green JM. Principles and practicalities of carrier screening: attitudes of recent parents. $\mathcal{f}$ Med Genet 1992;29:313-9.

21 Decruyenaere M, Evers-Kiebooms G, Denayer L, Van den Berghe $H$. Cystic fibrosis: community knowledge and attitudes towards carrier screening and prenatal diagnosis. Clin Genet 1992;41:189-96.

22 Denayer L, Evers-Kiebooms G, De Boeck K, van den Berghe $\mathrm{H}$. Reproductive decision making of aunts and uncles of a child with cystic fibrosis: genetic risk perception and attitudes toward carrier identification and prenatal diagnosis. Am F Med Genet 1992;44:104-11.

23 Watson EK, Mayall ES, Lamb J, Chapple J, Williamson R. Psychological and social consequences of community carrier screening programme for cystic fibrosis. Lance 1992;340:217-20

24 Clow CL, Scriver CR. Knowledge about attitudes toward genetic screening among high-school students: the TaySachs experience. Pediatrics 1977;59:86-91.

25 Mennie ME, Liston WA, Brock DJH. Prenatal cystic 
fibrosis carrier testing: designing an information leaflet to meet the specific needs of the target population. $7 \mathrm{Med}$ Genet 1992;29:308-12.

26 Watson EK, Mayall E, Chapple J, et al. Screening for carriers of cystic fibrosis through primary health care services. BMF 1991;303:504-7.

27 Watson EK, Marchant J, Bush A, Williamson R. Attitudes towards prenatal diagnosis and carrier screening for cystic fibrosis among the parents of patients in a paediatric cystic fibrosis clinic. 7 Med Genet 1992;29:490-1.

28 Fernandes MJG, Kaplan F, Clow CL, Hechtman P, Scriver CR. Specificity and sensitivity of hexosaminidase assays and DNA analysis for the detection of Tay-Sachs disease gene carriers among Ashkenazic Jews. Genet Epidemiol 1992;9:169-75.

29 Gold RJM, Maag UR, Neal JL, Scriver CR. The use of biochemical data in screening for mutant alleles and in genetic counselling. Ann Hum Genet 1974;37:315-26.

30 Zeesman S, Clow CL, Cartier L, Scriver CR. A private view of heterozygosity: eight-year follow-up study on carriers of Tay-Sachs gene detected by high school screening in

31 Kaplan F, Mitchell J, Ravone G, Fernandes L, Clow C, Scriver CR. Cystic fibrosis carrier detection by DNA test: a population study. Carrier frequencies and attitudes toward a test with imperfect sensitivity. Am $\mathcal{f}$ Hum Genet 1992;51:A268.

32 Rozen $\mathrm{R}$, De Braekeleer M, Daigneault J, et al. Cystic fibrosis mutations in French Canadians: three CFTR mutations are relatively frequent in a Quebec population with an elevated incidence of cystic fibrosis. $\mathrm{Am} \mathcal{F ~ M e d}$ Genet 1992;42:360-4.

33 Cutting GR, Antonarakis SE, Beutow KH, Kasch LM Rosenstein BJ, Kazazian $\mathrm{HH}$ Jr. Analysis of DNA polymorphism haplotypes linked to the cys North American black and Caucasian families suppo the existence of multiple mutations of the cystic fibrosis gene. Am f Hum Genet 1989;44:307-18.

34 Ferrie RM, Schwartz MJ, Robertson NH, et al. Development, multiplexing, and application of ARMS tests for common mutations in the CFTR gene. Am $\mathcal{f}$ Hum Genet 1992;51:251-62.

Appendix Questions referred to in table 3 and used in the follow up survey of phase II in the CF carrier testing project.

(1) Do you approve of genetic screening, in principle, in high schools to detect the silent carriers of recessive mutations causing diseases such as Tay-Sachs disease, thalassaemia, sickle cell anaemia, and cystic fibrosis?

(2) Does the negative test result mean that you cannot be carrying any cystic fibrosis mutation at all?

(3) If your partner were a carrier, would it affect your relationship?

(4) If you and your partner were both carriers of a cystic fibrosis mutation would you

(a) not have children?

b) take your chances and have children?

c) have children but take steps to have childre unaffected by cystic fibrosis; options that would allow a family to have a child without cystic fibrosis include adoption, artificial insemination by a donor, and prenatal diagnosis with selective abortion?

(d) don't know.

(5) Do you think carrier screening should take place:

(a) in senior high school?

b) when couples are planning to get married?

(c) when couples are planning to have a baby?

(d) don't know.

(e) should not be done at all. 